\title{
Miscellaneous behavioural observations of Malagasy birds
}

Charlie J. Gardner' and Louise D. Jasper

\begin{abstract}
Madagascar possesses a unique avifauna characterized by high endemism rates at species and higher taxonomic levels, but little is known about the behaviour, diets and interspecific interactions of many species. We present a number of opportunistic observations of Malagasy birds collected during 2012-2015, including a foraging association between Hook-billed vanga Vanga curvirostris and White-breasted mesite Mesitornis variegatus, aggressive interaction between a fledgling Madagascar cuckoo Cuculus rochii and its Common jery Neomixis tenella host, records of carnivory in Green-capped coua Coua ruficeps olivaceiceps and frugivory in Lafresnaye's vanga Xenopirostris xenopirostris, an unusual aggregation of Alpine swift Tachymarptis melba around a telecommunications tower, entrapment of Madagascar mannikin Lepidopygia nana in a spider's web, and anti-predator behaviour (mobbing) of potentially predatory reptiles in Souimanga sunbird Nectarinia souimanga, Madagascar magpie robin Copsychus albospecularis, Madagascar paradise flycatcher Terpsiphone mutata, common newtonia Newtonia brunneicauda and Crested drongo Dicrurus forficatus.
\end{abstract}

\section{RÉSUMÉ}

L'avifaune de Madagascar est unique, caractérisée par des taux d'endémisme élevés aux niveaux des espèces, genres, familles et ordres. Cependant, nous connaissons encore mal les comportements, les régimes alimentaires ou encore les interactions interspécifiques de nombreuses espèces. Sont présentées dans cette note une série d'observations opportunistes collectées au cours de la période 2012-2015, incluant : i) une interaction lors de la recherche de nourriture entre un Vanga écorcheur Vanga curvirostris et une paire de Mésite variée Mesitornis variegatus, ii) une interaction agressive entre un oisillon du Coucou de Madagascar Cuculus rochii et son hôte, une Petite éroesse Neomixis tenella, iii) la prédation d'un lézard (Tracheloptychus madagascariensis) par un Coua à tête verte Coua ruficeps olivaceiceps, iv) la frugivorie par un vanga de Lafresnaye Xenopirostris xenopirostris, v) une agrégation inhabituelle des Martinets à ventre blanc Tachymarptis melba autour d'une installation de télécommunication, vi) le

\author{
Correspondence: \\ Charlie J. Gardner \\ Durrell Institute of Conservation and Ecology (DICE) \\ School of Anthropology and Conservation, University of Kent \\ United Kingdom \\ Email: C.Gardner-399@Kent.ac.uk
}

piégeage d'un Capucin de Madagascar Lepidopygia nana dans une toile d'araignée (Nephila sp.), et vii) le harcèlement des reptiles incluant des serpents (Ithycyphus miniatus, Acrantophis madagascariensis) et un caméléon (Furcifer pardalis) par le Souimanga malgache Nectarinia souimanga, le Shama de Madagascar Copsychus albospecularis, le Tchitrec malgache Terpsiphone mutata, la Newtonie commune Newtonia brunneicauda et le Drongo malgache Dicrurus forficatus.

\section{is}

Madagascar possesses a unique avifauna characterized by high levels of endemism at species and higher taxonomic levels. Onehundred-and-six out of 256 regularly occurring species are endemic, while 40 genera and six families are restricted to Madagascar and the neighbouring Comoros archipelago (Safford and Hawkins 2013). Unfortunately, the paucity of researchers and publishing observers on the island means that little is known about the behaviour, diets and interspecific interactions of many species, yet an improved understanding of species ecology may be useful for conservation efforts as well as for academic reasons. Here, we contribute to filling this gap with a series of opportunistic field observations, largely concerning endemic species, collected during the period 2012-2015 from around Madagascar (additional behavioural observations can be found in Gardner et al. 2011; Gardner and Jasper 2014). Herein we follow the taxonomy adopted by Safford and Hawkins (2013).

ASSOCIATION BETWEEN WHITE-BREASTED MESITE MESITORNIS VARIEGATUS, MADAGASCAR BLUE VANGA CYANOLANIUS MADAGASCARINUS, AND HOOK-BILLED VANGA VANGA CURVIROSTRIS. At 1111h on 29 April 2015, south of Campement Anilotra (Campement des Anglais) in Ankarana National Park (E049 06' 27", S12 ${ }^{\circ} 54^{\prime}$ 37", Diana Region), we encountered a mixed flock containing Madagascar blue vanga, crested drongo Dicrurus forficatus and Red-tailed vanga Calicalicus madagascariensis. We tried to elicit a response 


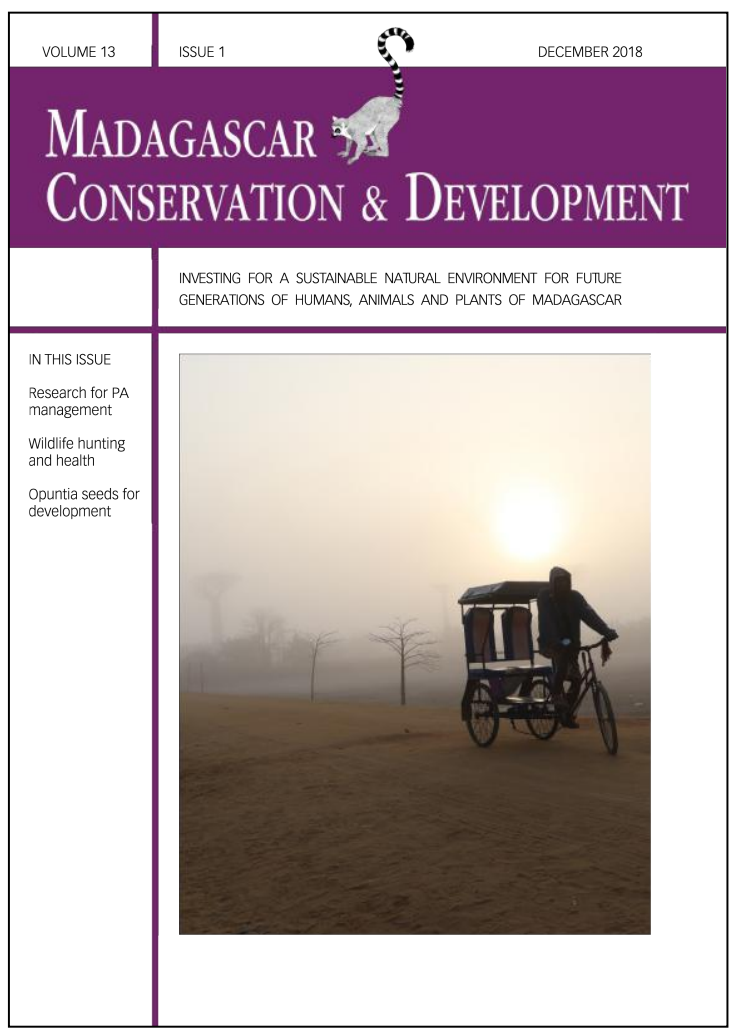

Madagascar Conservation \& Development is the journal of Indian Ocean e-Ink. It is produced under the responsibility of this institution. The views expressed in contributions to MCD are solely those of the authors and not those of the journal editors or the publisher.

All the Issues and articles are freely available at http://www.journalmcd.com

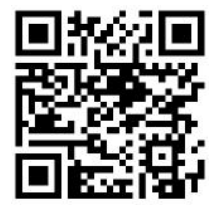

Contact Journal MCD

info@journalmcd.net for general inquiries regarding MCD funding@journalmcd.net to support the journal

Madagascar Conservation \& Development Institute and Museum of Anthropology

University of Zurich

Winterthurerstrasse 190

$\mathrm{CH}-8057$ Zurich

Switzerland

Indian Ocean e-Ink

Promoting African Publishing and Education

www.ioeink.com

Missouri Botanical Garden (MBG)

Madagascar Research and Conservation Program

Missouri Botanical Garden

BP 3391

Antananarivo, 101, Madagascar 
from a Madagascar blue vanga with the use of call playback (using a recording from Huguet and Chapuis 2003), but the call instead triggered a duet by a nearby pair of White-breasted mesite, and this duet was in turn answered by a duet from a distant pair of conspecifics. In total we played the call of Madagascar blue vanga three times and each time it elicited a duet from the Whitebreasted mesite pair.

Having been obscured by dense undergrowth, the Whitebreasted mesites came into view after several minutes as they foraged in the leaf litter. They were followed at a distance of about $2 \mathrm{~m}$ by an adult Hook-billed vanga, which hopped through the undergrowth, perching in shrubs and lianas at a height of about $1 \mathrm{~m}$, constantly observing the mesites foraging beneath. We observed the birds for approximately $10 \mathrm{~min}$, during which time the vanga remained close to the mesites and watched their movements closely (though sometimes distracted by us), and regularly emitted a muted version of its 'whistle' call. It also emitted a soft, cat-like 'meow' call and a number of bill snaps, often in response to the singing of the mesites. However, we did not see the vanga descend to the ground to take prey, or capture any prey in the vegetation.

The three species of mesite (Mesitornithidae) forage in pairs or small groups in areas of thick leaf litter on the forest floor, slowly and deliberately searching amongst fallen leaves for invertebrates. They may be followed by a range of birds which take invertebrates flushed by their actions. For example, groups of Subdesert mesite Monias benschi are frequently followed by Crested drongo (85/174 mesite group encounters, seddon 2001) and more rarely by Lafresnaye's vanga Xenopirostris xenopirostris and Madagascar hoopoe Upupa marginata $(1.2 \%$ and $0.8 \%$ of group encounters, Seddon and Tobias 2013). Species known to follow groups of White-breasted mesite include crested drongo, Madagascar paradise flycatcher Terpsiphone mutata, Madagascar magpie robin copsychus albospecularis, Long-billed tetraka Bernieria madagascariensis and Rufous vanga Schetba rufa (Langrand 1990, Eguchi 1998, Hawkins 2013). However, this behaviour has never been observed in Hook-billed vanga. Since this species consumes vertebrates much more frequently than other vangas (Schulenberg and Hawkins 2013a), we speculate that the bird may have been hunting for Brookesia dwarf chameleons (Chamaeleonidae), which forage within leaf litter and were said to be common in that area by our guide.

CARNIVORY BY GREEN-CAPPED COUA COUA RUFICEPS OLIVACEICEPS. On 6 April 2014 at 0931h, at the Arboretum

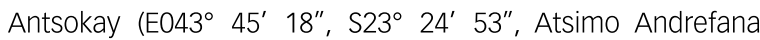
Region), we observed an adult Green-capped coua predating a Madagascar girdled lizard Tracheloptychus madagascariensis (Gerrhosauridae) (Figure 1). The lizard was captured on the ground in an area of bare sand.

The nine extant species of Coua are omnivorous, feeding on insects and other invertebrates, plant matter (fruits, flower buds, seeds, tree gum), small reptiles (skinks, geckos, chameleons) and the eggs of reptiles and birds (Milon et al. 1973, Goodman et al. 1997, Safford and Hawkins 2013). However, this is the first record of vertebrate carnivory in either subspecies of Coua ruficeps (Safford and Hawkins 2013). The only remaining coua species not known to consume vertebrates is the Running coua Coua cursor (Safford and Hawkins 2013); but this may simply reflect a lack of observations.

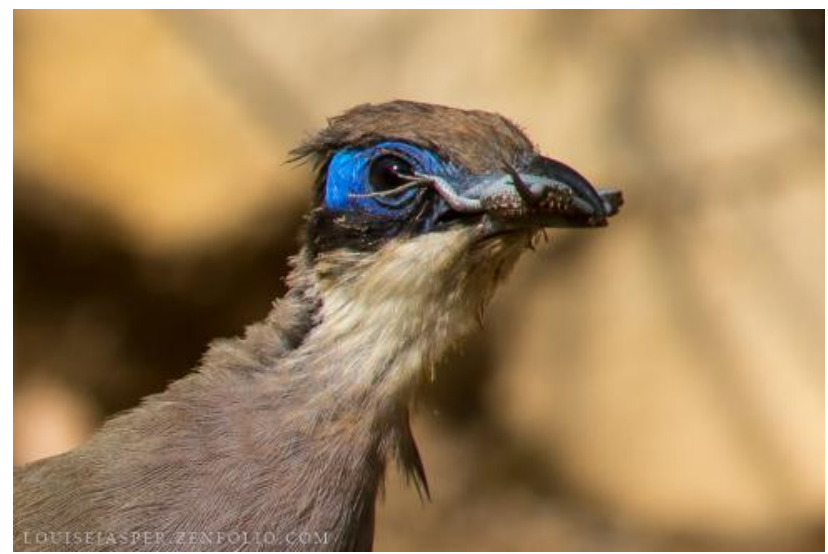

Figure 1. Green-capped coua Coua ruficeps olivaceiceps predating a Madagascar girdled lizard Tracheloptychus madagascariensis, Arboretum Antsokay, southwest Madagascar, 6 April 2014. (Photo: Louise Jasper)

AQUATIC HABITAT USE BY VERREAUX'S COUA COUA VERREAUXI. On 18 April 2013 at 1004h, we observed an adult Verreaux's coua in aquatic vegetation on a small tributary of the Onilahy River, south of the spring known as Andoharano (E043 46' 56", S23 32' 36", Atsimo Andrefana Region) (Figure 2). The bird appeared to be foraging within a dense, $1.5 \mathrm{~m}$ tall bed of the fern Acrostichum aureum, but when disturbed by the approach of our vessel it flew into the spiny thicket vegetation on the slopes of the limestone plateau on the opposite bank. Verreaux's coua is endemic to the South Malagasy Spiny Forest Endemic Bird Area (Stattersfield et al. 1998), which covers the driest region of the country and contains few wetlands. The habitat adjacent to the wetland, into which the coua flew, was typical of the species - described as "spiny thicket on and around limestone outcrops of Mahafaly Plateau and close to coast, often dominated by plants in the families Didiereaceae and Euphorbiaceae" (Goodman 2013a). However, we are not aware of any previous records of the use of aquatic vegetation by this species.

UNUSUAL INTERACTION BETWEEN FLEDGLING MADAGASCAR CUCKOO CUCULUS ROCHII AND ITS COMMON JERY NEOMIXIS TENELLA HOST. On 30 December 2012 at 1121h, between

Talatakely and Vatoharanana in Ranomafana National Park (approx. E047 ${ }^{\circ} 5^{\prime} 30^{\prime \prime}, \mathrm{S} 21^{\circ} 16^{\prime} 34^{\prime \prime}$, Haute Matsiatra Region), we observed an interaction involving a fledgling Madagascar cuckoo and its host, a Common jery (Figure 3). The host perched next to the cuckoo and began feeding it, but within $1 \mathrm{sec}$ the cuckoo had

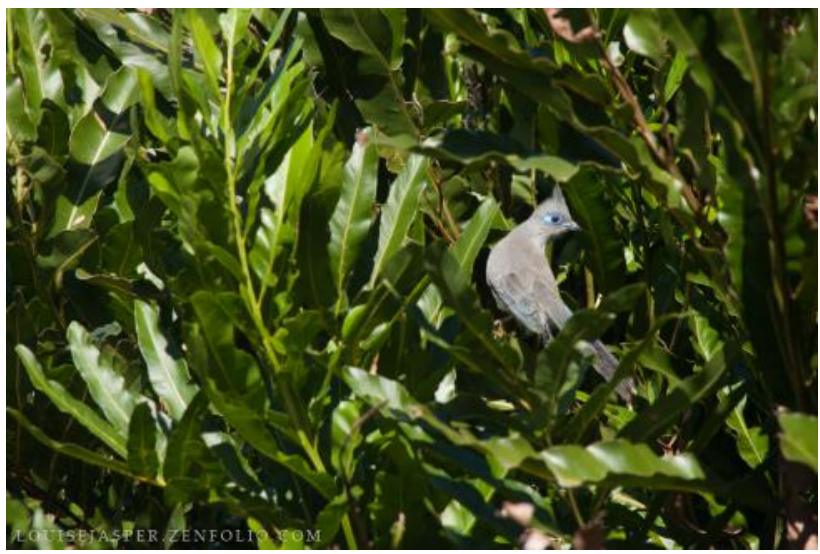

Figure 2. Verreaux's coua Coua verreauxi using aquatic vegetation (a bed of the fern Acrostichum aureum), Onilahy River, 18 April 2013. (Photo: Louise Jasper) 

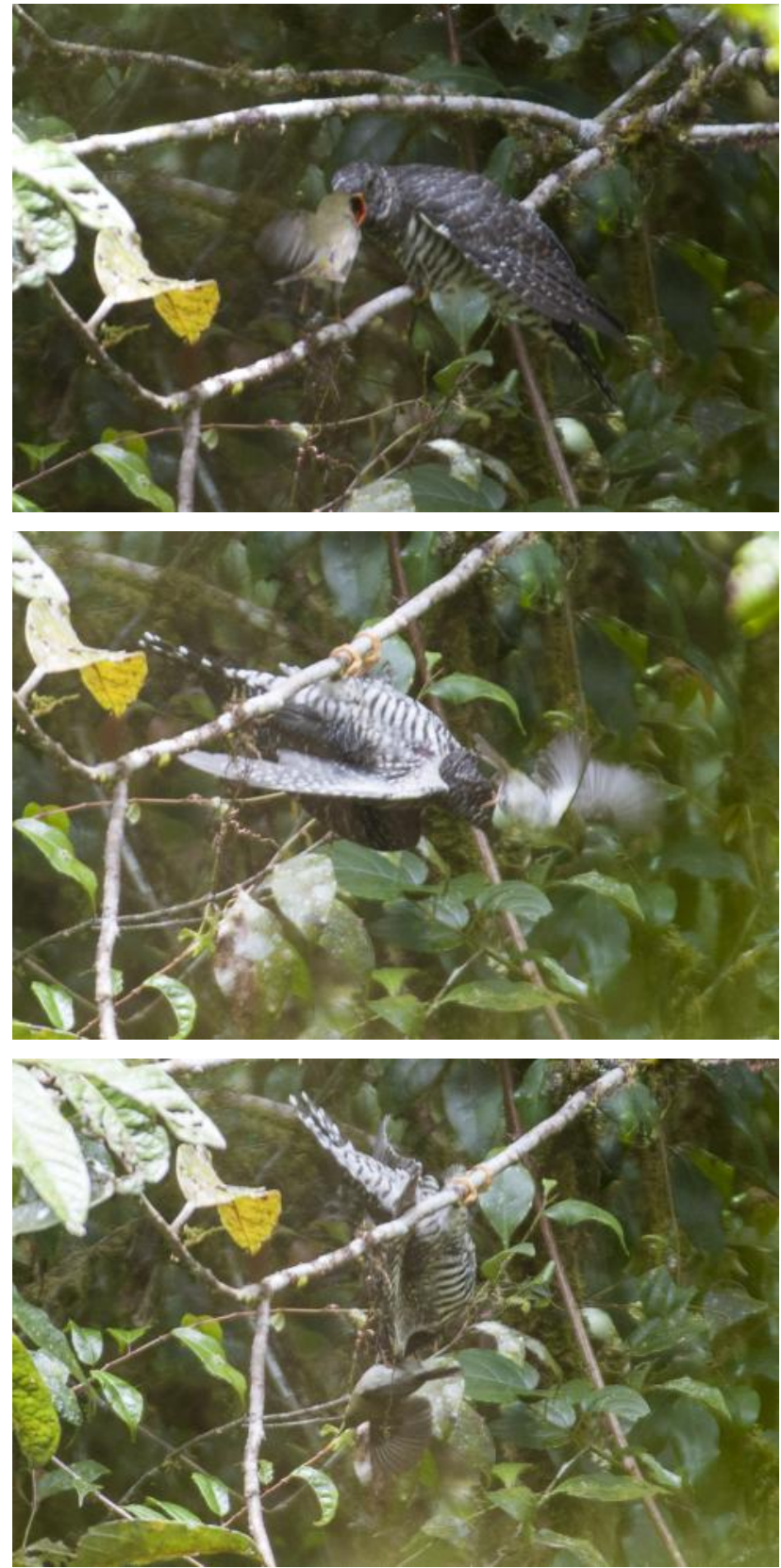

Figure 3. Sequence of images showing the temporary capture of a Common jery Neomixis tenella host by a fledgling Madagascar cuckoo Cuculus rochii, Ranomafana National Park, Madagascar, 30 December 2012. (Photos: Louise Jasper)

grasped the jery by the leg with its bill. The host immediately began struggling, unbalancing the cuckoo from its perch. However, the cuckoo retained its grip on the jery while dangling suspended from the branch. After $4-5 \mathrm{sec}$ of continued struggle, the cuckoo released its grip on the branch and fell, at which point the jery escaped.

We are aware of only one comparable incident, in which a Common cuckoo Cuculus canorus grasped the head of its host, a Dunnock Prunella modularis, as it delivered food to its gape, and killed it (Hens 1949). Both incidents likely represent 'overenthusiastic' attempts to grasp food by the cuckoo parasites, rather than predation attempts upon their hosts (N. B. Davies 2017, pers. comm.).
UNUSUAL AGGREGATION OF ALPINE SWIFT TACHYMARPTIS MELBA. On 28 May 2012 at 1137h, LDJ observed a flock of at least 215 Alpine swift flocking around the emitters of a telecommunications pylon in the village of Belalanda (E043 $38^{\prime}$ $42^{\prime \prime}$, S23 17' 48", Atsimo Andrefana Region) (Figure 4). The birds appeared to be attracted to particular panels which they flew towards feet first, although they did not land. Magnification of the images reveals no clouds of insects around the tower, and there were no nests on the structure.

There is evidence that electromagnetic radiation can interfere with bird orientation (Engels et al. 2014), however most research has focused on low frequencies $(<50 \mathrm{kHz})$ rather than the high frequencies (typically $>900 \mathrm{kHz}$ ) used in telecommunication signals (C. Meier 2018, pers. comm.). The Alpine swift is a presumed resident in Madagascar which forms nesting colonies on cliffs and buildings elsewhere in its range. However, its nesting sites in Madagascar remain unknown (Safford 2013a). We are not aware of any information on maximum flock sizes of this species in the southern hemisphere though 200+ individuals appears to be unusually large: in Europe flocks of more than 1000 individuals have been observed (C. Meier 2018, pers. comm.).

MOBBING OF CHAMELEON BY SOUIMANGA SUNBIRD NECTARINIA SOUIMANGA. At 1120h on 14 April 2015, on the southernmost limestone karst (tsingy) outcrop of the

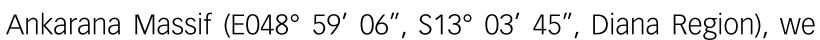
observed two adults and one juvenile Souimanga sunbird mobbing a large panther chameleon Furcifer pardalis (Chamaeleonidae; total length $<38 \mathrm{~cm}$, Glaw and Vences 2007). All three birds were alarm calling from branches to the side of and behind the chameleon, and flew above and around it for several minutes, but did not approach it from the front. Safford (2013b) notes that Souimanga sunbird is aggressive and may relentlessly mob predators, singly or in groups. Our observations show that Souimanga sunbirds recognize large chameleons as potential predators, however we are aware of only one record of a chameleon (Furcifer oustaleti) predating birds in Madagascar (García and Vences 2002).

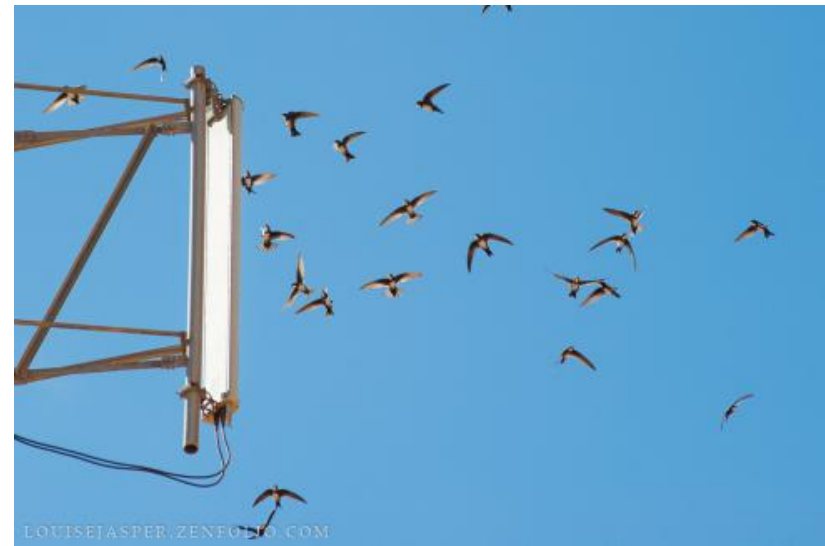

Figure 4. Flock of Alpine swift Tachymarptis melba flying around emitter of telecommunications tower in Belalanda, southwest Madagascar, 28 May 2012. (Photo: Louise Jasper) 
SNAKE MOBBING BY COMMON NEWTONIA NEWTONIA BRUNNEICAUDA, MADAGASCAR MAGPIE ROBIN COPSYCHUS ALBOSPECULARIS, MADAGASCAR PARADISE FLYCATCHER TERPSIPHONE MUTATA AND SOUIMANGA SUNBIRD NECTARINIA SOUIMANGA. On 20 March 2015 at $1202 \mathrm{~h}$ at Baie

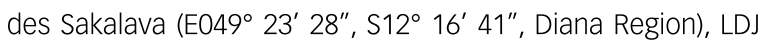
was alerted by the alarm calls of Madagascar magpie robin and Souimanga sunbird to an area of shrubby vegetation within a patch of degraded coastal thicket. On closer approach she found a mixed aggregation including Common newtonia, Madagascar magpie robin, Madagascar paradise flycatcher and Souimanga sunbird, mobbing an adult-sized Ithycyphus miniatus (Lamprophiidae; total length $<170 \mathrm{~cm}$, Glaw and Vences 2007). The snake was initially moving across the ground before climbing into a bush after several minutes: all four bird species continued to alarm call vociferously from distances between $1 \mathrm{~m}$ and $5 \mathrm{~m}$, though none physically approached the snake. The snake continued to hunt for over 30 min during which Madagascar magpie robin and Souimanga sunbird continued to alarm call persistently, with Common newtonia and Madagascar paradise flycatcher also continuing to alarm though more intermittently. During this time the snake caught and consumed a probable House mouse Mus musculus, and was closely approached by three human observers, but the birds continued to alarm throughout. Although none of these species are noted as known snake prey items (Safford and Hawkins 2013), our observations suggest that all recognize snakes as potential predators.

FRUGIVORY IN LAFRESNAYE'S VANGA XENOPIROSTRIS XENOPIROSTRIS. On 25 November 2012 at 0631h, LDJ observed a male Lafresnaye's vanga eating the fruit of Commiphora lamii (Burseraceae) in degraded coastal spiny thicket south of the village of Anakao (E043 $38^{\prime} 35^{\prime \prime}$, S23 40 11", Atsimo Andrefana Region) (Figure 5). The bird picked the ripe fruit with its bill, but then held it against a branch with its foot in order to remove and eat the fleshy aril before dropping the seed (as described for White-headed vanga Artamella viridis eating the red arils of Commiphora guillaumini fruit, Böhning-Gaese et al. 1995): it was observed feeding on the fruit continuously for about five minutes. Since the seeds were neither destroyed nor swallowed but dropped around the tree, the bird is unlikely to function as either a seed predator or a seed disperser.

Members of the Vangidae are primarily insectivorous, though the larger species take vertebrates and "a few species consume at least some fruit" (Schulenberg 2013a). Species recorded eating fruit include Madagascar blue vanga, Chabert vanga Leptopterus chabert (including red arils of Commiphora fruit), Bernier's vanga Oriola bernieri and White-headed vanga (Benson et al. 1977, Böhning-Gaese et al. 1995, 1999, Schulenberg 2013b, Schulenberg and Hawkins 2013b): our observation is the first record of frugivory in the genus Xenopirostris. The 44 Malagasy species of Commiphora are widespread in the country's dry regions (Schatz 2008, Gostel et al. 2016). The oily, energy-rich arils are consumed by birds including the Lesser vasa parrot Coracopsis nigra, Greater vasa parrot $C$. vasa, Common jery and now three species of vanga, as well as a lemur (Verreaux's sifaka Propithecus verreauxi), and the ant Aphaenogaster swammerdami (Böhning-Gaese et al. 1995, 1999).

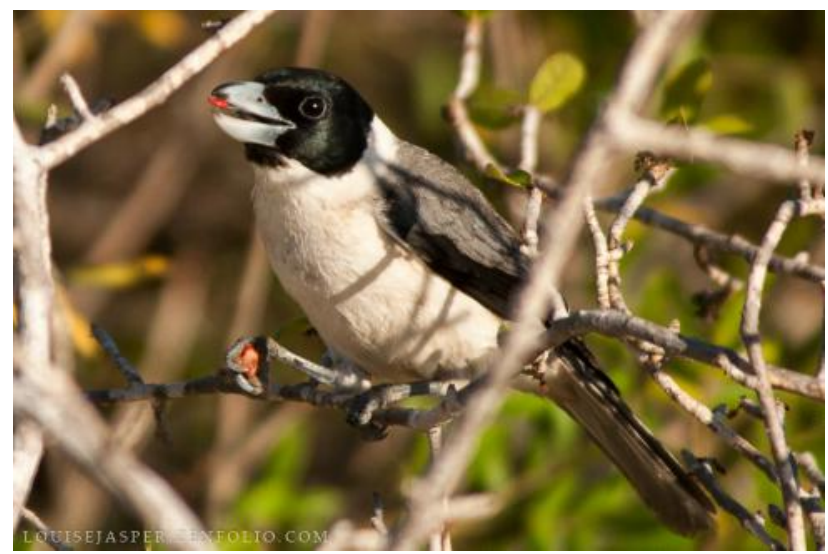

Figure 5. Male Lafresnaye's vanga Xenopirostris xenopirostris eating fruit of Commiphora lamii, Anakao, 25 November 2012. (Photo: Louise Jasper)

MOBBING OF BOA BY CRESTED DRONGO DICRURUS FORFICATUS. On 29 December 2014 at Anjajavy Lodge (E047

$13^{\prime} 40^{\prime \prime}, S 14^{\circ} 59^{\prime} 27^{\prime \prime}$, Sofia Region), LDJ observed a Crested drongo mobbing a large (total length $<320 \mathrm{~cm}$, Glaw and Vences 2007) Madagascar ground boa Acrantophis madagascariensis (Boidae) that was lying motionless against a log. The bird aggressively mobbed the snake in flight, approaching to within approximately $1 \mathrm{~m}$, and emitted a loud, metallic alarm call that we had not previously heard.

The crested drongo is a very aggressive bird that frequently mobs raptors and other large birds (Safford 2013c), as well as a captive Ring-tailed lemur Lemur catta (van Someren 1947). However, we are not aware of any records of this species mobbing snakes. The Madagascar ground boa is a predominantly terrestrial ambush predator, and thus unlikely to predate a mid-stratum sally gleaner such as the Crested drongo.

ENTRAPMENT OF MADAGASCAR MANNIKIN LEPIDOPYGIA NANA IN SPIDER WEB. At 1740h on 17 June 2015, about

15 min after sunset, we witnessed a Madagascar mannikin fly into, and become trapped within, the web of a golden orb spider, Nephila cf. inaurata, in a hotel garden in urban Morondava (E044 ${ }^{\circ}$ $16^{\prime} 05^{\prime \prime}, \mathrm{S} 20^{\circ} 17^{\prime} 59^{\prime \prime}$, Menabe Region). The web was suspended between two trees at a height of approx. $3.5 \mathrm{~m}$. The bird struggled frantically to escape and the large, female spider immediately began to approach it, reaching out to touch it with its forelegs. After about $15 \mathrm{sec}$ the bird escaped the web and was able to fly away apparently unharmed.

Entrapment of birds in spider webs is a relatively rare event, a recent review revealing only 69 reports involving 54 bird species in 24 families: of these, four involved members of the mannikin family, Estrildidae (Brooks 2012). Of those in which the spider was identified, $50 \%(n=23)$ were in the genus Nephila. Results suggest that birds may survive if they escape the web before being wrapped in silk by the spider $(n=8)$, but otherwise invariably die unless released (Brooks 2012).

\section{ACKNOWLEDGEMENTS}

We thank L. Wilmé, N. B. Davies (expert on cuckoo breeding behaviour), C. Meier (expert on migration ecology of Alpine swift) and E. Dunn for discussions and help with the literature, and Rokiman Letsara for identification of the fruit in Figure 5. 


\section{REFERENCES}

Benson, C. W., Colebrook-Robjent, J. F. R. and Williams, A. 1977. Contribution à I'ornithologie de Madagascar. Oiseau et Revue Française d'Ornithologie 47: 41-64, 168-191.

Böhning-Gaese, K., Gaese, B. H. and Rabemanantsoa, S. B. 1995. Seed dispersal by frugivorous tree visitors in the Malagasy tree species Commiphora guillaumini. Ecotropica 1: 41-50.

Böhning-Gaese, K., Gaese, B. H. and Rabemanantsoa, S. B. 1999. Importance of primary and secondary dispersal in the Malagasy tree Commiphora guillaumini. Ecology 80: 821-832.

Brooks, D. M. 2012. Birds caught in spider webs: a synthesis of patterns. The Wilson Journal of Ornithology 124, 2: 345-353. <https://doi.org/10.1676/11-148.1>

Eguchi, K. 1998. The white-breasted mesite: rufous vanga's beater. Working Group on Birds in the Madagascar Region Newsletter 8: 5-6.

Engels, S., Schneider, N. L., Lefeldt, N., Hein, C. M., Zapka, M., et al. 2014. Anthropogenic electromagnetic noise disrupts magnetic compass orientation in a migratory bird. Nature 509: 353-356. <https://doi.org/10.1038/nature13290>

García, G. and Vences, M. 2002. Furcifer oustaleti (Oustalet's Chameleon). Diet. Herpetological Review 33, 2: 134-135.

Gardner, C. J. and Jasper, L. D. 2014. A record of vertebrate carnivory by the crested drongo (Dicrurus forficatus). Malagasy Nature 8: 105-106.

Gardner, C. J., Jasper, L. D. and Vincke, X. 2011. Sakalava weaver (Ploceus sakalava) nesting association with raptors: an alternative hypothesis. Malagasy Nature 5: 129-131.

Glaw, F. and Vences, M. 2007. A Field Guide to the Amphibians and Reptiles of Madagascar. Third Edition. Vences \& Glaw Verlag, Koln.

Goodman, S. M. 2013a. Verreaux's Coua Coua verreauxi. In: The Birds of Africa. Volume VIII: The Malagasy Region. R. J. Safford and A. F. A. Hawkins (eds.), pp 543-544. Christopher Helm, London.

Goodman, S. M., Pidgeon, M., Hawkins, A. F. A. and Schulenberg, T.S. 1997. The birds of south-eastern Madagascar. Fieldiana (Zoology), New Series, 87: 1-132.

Gostel, M. R., Phillipson, P. B. and Weeks, A. 2016. Phylogenetic reconstruction of the Myrrh genus, Commiphora (Burseraceae), reveals multiple radiations in Madagascar and clarifies infrageneric relationships. Systematic Botany 41, 1: 67-81. <https://doi.org/10.1600/036364416X690598>

Hawkins, A. F. A. 2013. White-breasted mesite, Mesitornis variegatus. In: The Birds of Africa. Volume VIII: The Malagasy Region. R. J. Safford and A. F. A. Hawkins (eds.), pp 339-341. Christopher Helm, London.

Hens, P. 1949. Junge kockock (Cuculus canorus) doodt een van zijn pleegouders (young cuckoo kills one of its fosterers). Limosa 22: 329-330.

Huguet, P. and Chappuis, C. 2003. Oiseaux de Madagascar, Mayotte, Comoros, Seychelles, Réunion. Maurice. Société d'Etudes Ornithologiques de France, Paris.

Langrand, O. 1990. Guide to the Birds of Madagascar. Yale University Press, New Haven.

Milon, P., Petter, J.-J. and Randrianasolo, G. 1973. Oiseaux. Faune de Madagascar 35. ORSTOM and CNRS, Antananarivo.

Safford, R. J. 2013a. Alpine Swift, Tachymarptis melba. In: The Birds of Africa. Volume VIII: The Malagasy Region. R. J. Safford and A. F. A. Hawkins (eds.), pp 599-601. Christopher Helm, London.

Safford, R. J. 2013b. Souimanga sunbird, Nectarinia souimanga. In: The Birds of Africa. Volume VIII: The Malagasy Region. R. J. Safford and A. F. A. Hawkins (eds.), pp 775-779. Christopher Helm, London.

Safford, R. J. 2013c. Crested drongo, Dicrurus forficatus. In: The Birds of Africa. Volume VIII: The Malagasy Region. R. J. Safford and A. F. A. Hawkins (eds.), pp 848-850. Christopher Helm, London.

Safford, R. J. and Hawkins, A. F. A. 2013. The Birds of Africa. Volume VIII: The Malagasy Region. Christopher Helm, London

Schatz, G. E. 2001. Generic Tree Flora of Madagascar. Royal Botanic Gardens, Kew and Missouri Botanical Garden, St Louis.
Schulenberg, T. S. 2013a. Family Vangidae: Vangas. In: The Birds of Africa. Volume VIII: The Malagasy Region. R. J. Safford and A. F. A. Hawkins (eds.), p 802. Christopher Helm, London.

Schulenberg, T. S. 2013b. Chabert vanga, Leptopterus chabert. In: The Birds of Africa. Volume VIII: The Malagasy Region. R. J. Safford and A. F. A. Hawkins (eds.), pp 819-821. Christopher Helm, London.

Schulenberg, T. S. and Hawkins, A. F. A. 2013a. Hook-billed vanga, Vanga curvirostris. In: The Birds of Africa. Volume VIII: The Malagasy Region. R. J. Safford and A. F. A. Hawkins (eds.), pp 823-825. Christopher Helm, London.

Schulenberg, T. S. and Hawkins, A. F. A. 2013b. Bernier's vanga, Oriola bernieri. In: The Birds of Africa. Volume VIII: The Malagasy Region. R. J. Safford and A. F. A. Hawkins (eds.), pp 830-832. Christopher Helm, London.

Seddon, N. 2001. Ecology, Communication and Conservation of the Subdesert Mesite, Monias benschi. Unpubl. Ph.D. thesis, University of Cambridge, Cambridge.

Seddon, N. and Tobias, J A. 2013. Subdesert mesite, Monias benschi. In: The Birds of Africa. Volume VIII: The Malagasy Region. R. J. Safford and A. F. A. Hawkins (eds.), pp 341-344. Christopher Helm, London.

van Sommeren, V. D. 1947. Field notes on some Madagascar birds. Ibis 89: 235-267.

Stattersfield, A., Crosby, M., Long, A. and Wege, D. 1998. Global Directory of Endemic Bird Areas. BirdLife International, Cambridge. 